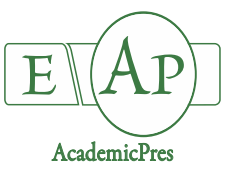

Barabasz-Krasny B et al. (2020)
Notulae Botanicae Horti Agrobotanici Cluj-Napoca 48(3):1 194-1209
DOI: $10.15835 /$ nbha48311937
Research Article

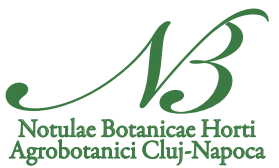

\title{
The role of light in the adaptation of Thymus praecox Opiz subsp. praecox for diverse habitat conditions
}

\author{
Beata BARABASZ-KRASNY ${ }^{1}$, Katarzyna MOŻDŻEŃ ${ }^{1 *}$, \\ Anna SOETYS-LELEK ${ }^{2}$, Ingrid TURISOVÁ ${ }^{3}$ \\ ${ }^{1}$ Pedagogical University of Krakow, Institute of Biology, Podchorążych 2 St.,30-084 Kraków, \\ Poland; beata.barabasz-krasny@up.krakow.pl; katarzyna.mozdzen@up.krakow.pl ('corresponding author) \\ 2Ojcow National Park,32-045Sułoszowa,Ojców 9, Poland; ana_soltys@wp.pl \\ ${ }^{3}$ Matej Bel University in Banska Bystrica, Faculty of Natural Sciences, Department of Biology and Ecology, Tajovského 40, Banská \\ Bystrica97401, Slovakia; ingrid.turisova@umb.sk
}

\begin{abstract}
The light decides about the course and efficiency of photochemical processes, being an important component of the surrounding environment shaping the plant composition in specific conditions. Thymus praecox subsp. praecox belongs to endangered taxa due to preferences for open habitats, which as a result of natural succession are exposed to overgrowth and shading with forest-scrub vegetation. In this study, an attempt was made to check the physiological activity of creeping thyme in changing environmental conditions prevailing on isolated stands in the Ojców National Park (Southern Poland). The increase in fresh and dry mass and the percentage of water in plants were determined, the content of chlorophyll $a$ and $b$ was measured, the intensity of chlorophyll a fluorescence was examined and the degree of electrolytes leakage through cell membranes was checked. The main aim was to determining the optimal habitat conditions for this taxon, which could help protect it. Based on the conducted research it was found, among others higher mass increase in plants from a sunny stand. Regardless of the measurement period, an increase in chlorophyll $a$ and $b$ content and a higher degree of cell membranes destabilisation in plants from a partially shaded stand was observed. The obtained results show, that $T$. praecox subsp. praecox characterises small habitat flexibility - even partial shade is not a convenient habitat for it. To optimal development, this subspecies requires conditions with high light availability. Creeping thyme is a heliophilic and thermophilic taxa and the sunny stands are optimal for it.
\end{abstract}

Keywords: morphological plasticity; Ojców National Park; physiological activity; protected species; Southern Poland; Thymus praecox subsp. praecox

\section{Introduction}

During the growing season, solar radiation reaching the Earth's surface changes significantly (Théry, 2001; Yang et al., 2018b). The photosynthetic apparatus of plants, due to different light conditions, has built defense mechanisms against the effects of different photosynthetically active radiation (PAR) (Carvalho et al., 2011; Bayat et al., 2018). Plants have created physical and endogenous barriers absorbing or dispersing excess solar radiation (e.g. Smith, 1982; Steyn et al., 2002; Albert et al., 2009). The morphological plasticity of plants 
belonging to the same species is illustrated by the fact that the same set of genes can create different phenotypes when exposed to different environmental factors. Therefore, morphological plasticity is assigned a key role in the adaptation of plants to changing environmental conditions (Frank et al., 2013). Specifying the species requirements for the environment, i.e. defining its ecological niche or available habitat (Harper, 1981), is particularly important for endangered taxa, such as, e.g. creeping thyme Thymus praecox Opiz. subsp. praecox.

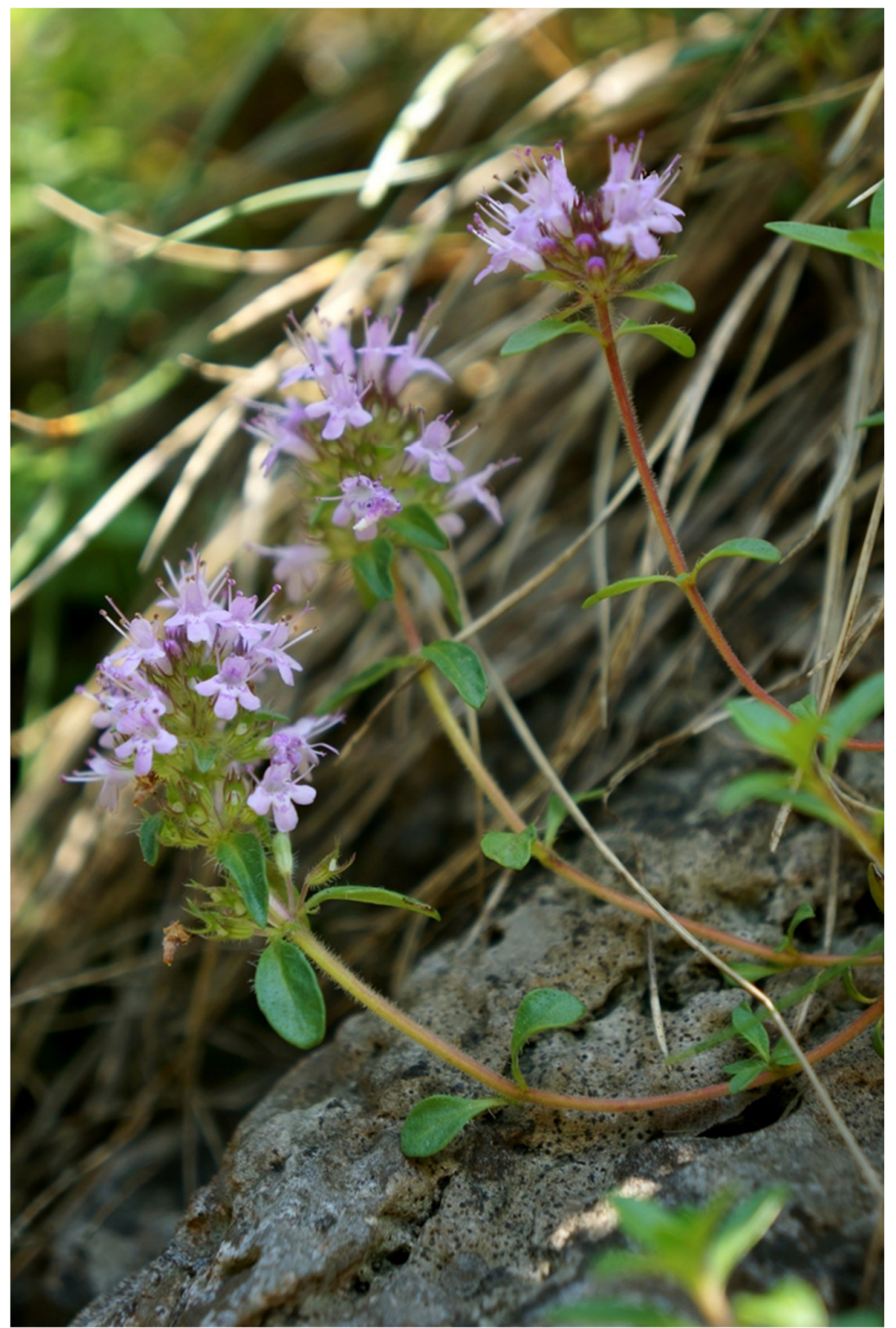

Figure 1. A blooming specimen of creeping thyme Thymus praecox Opiz subsp. praecox - Ojców, June 2018 (Photo A. Sołtys-Lelek) 
Thymus praecox subsp. praecox is one from 8 included taxa of Thymus praecox Opiz from sect. Serpyllum (Euro+Med 2006-) with islet occurrence in Europe (Meusel et al., 1978; Duchoň, 2012). In Poland, it grows only in southern part, in Ojców National Park - ONP (N - 1946'55,979"E 50¹5'4,086"N; E -

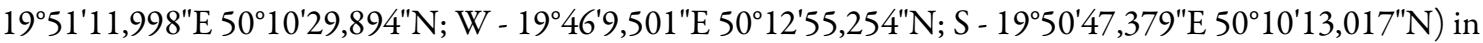
the Prądnik Valley (Dolina Prądnika), between Ojców and Prądnik Korzkiewski, and in the central and upper parts of the Sąspowska Valley (Dolina Sąspowska). Here, the rock turf Festucetum pallentis (Kozł. 1928) Kornaś 1950 (Biderman and Bąba, 2001) is the habitat of T. praecox subsp. praecox.

T. praecox is a semi-shrub with creeping stems that usually have barren tips and with laterally growing flowering branchlets. It has stiff, blade-like leaves; the lateral nerves on the underside of the leaves are quite thick, and the highest pair connects to the main nerve into a short thickened marginal nerve (Rutkowski, 2004). Flowering shoots of this species are evenly hairy, and leaves on the flowering branchlets become gradually larger towards the top (Figure 1). Leafed branchlets grow from terminal or lateral buds located on various older parts of the plant, often under the soil surface. In ONP it forms small tufts of individuals, usually vegetative reproducing (Biderman, 1991). The taxon has been entered in the "Polish Red Book of Plants" with the status CR - critically endangered (Biderman and Bąba, 2001), and it is in the "Red list of vascular plants in Poland" with the status E - threatened of extinction, critically endangered (Zarzycki and Szelagg, 2006). In Poland, the species is under strict legal protection and requires active conservation measures (item 1.388 according to RMS, 2014 - Rozporządzenie Ministra Środowiska z dnia 9 października 2014 r. w sprawie ochrony gatunkowej roślin Dz. U. 16 października 2014 r. Poz. 1409). The succession of forest and shrub vegetation, and the ensuing shading of sites, is a factor that threatens its survival. There are few publications on this taxon in the literature. They concern cytological, genetic and biochemical issues, some of its subspecies (Trela-Sawicka, 1972; Mártonfi and Mártonfiová, 1996; Avci, 2011; Karbstein et al., 2019).

The aim of this study was to compare the physiological activity of Thymus praecox subsp. praecox specimens growing in different habitat conditions, on sunny and partially shaded stands. Attempts were made to determine the effect of light intensity on: the fresh and dry mass and the water content of shoots $(i)$, the chlorophyll $a$ and $b$ content (ii), the chlorophyll $a$ fluorescence intensity (iii) and the degree of destabilisation of plant cell membranes $(i v)$. These explorations aimed at understanding physiology in general and at determining the optimal habitat conditions for this rare and endangered taxon, what could help protect it in the future.

\section{Materials and Methods}

\section{Plant material}

Thymus praecox subsp. praecox shoots were collected in situ from the natural habitat of the Ojców National Park (permission DLP-III-4102-661/47342/13/MD) on three measurement dates: beginning of species vegetation (May), optimum vegetation (June) and end of vegetation (July) 2018, from two stands: SP Maidens' Rocks (Skały Panieńskie) and K - beneath Krukowski's Rock (Skała Krukowskiego) (Figure 2).

\section{Research stands}

In order to characterise the designated test stands, the following measurements were taken: photosynthetically active radiation intensity (PAR) (light intensity meter: model 189, Li-Cor, Inc, Lincoln, USA), ambient temperature and relative humidity (digital hygrometer: PWT 221, Elmetron, Poland). Stand 1 - Maidens' Rocks (SP) was characterised by higher light intensity, higher temperature and lower air humidity, compared to the stand 2 - Krukowski's Rock (K) (Table 1). 


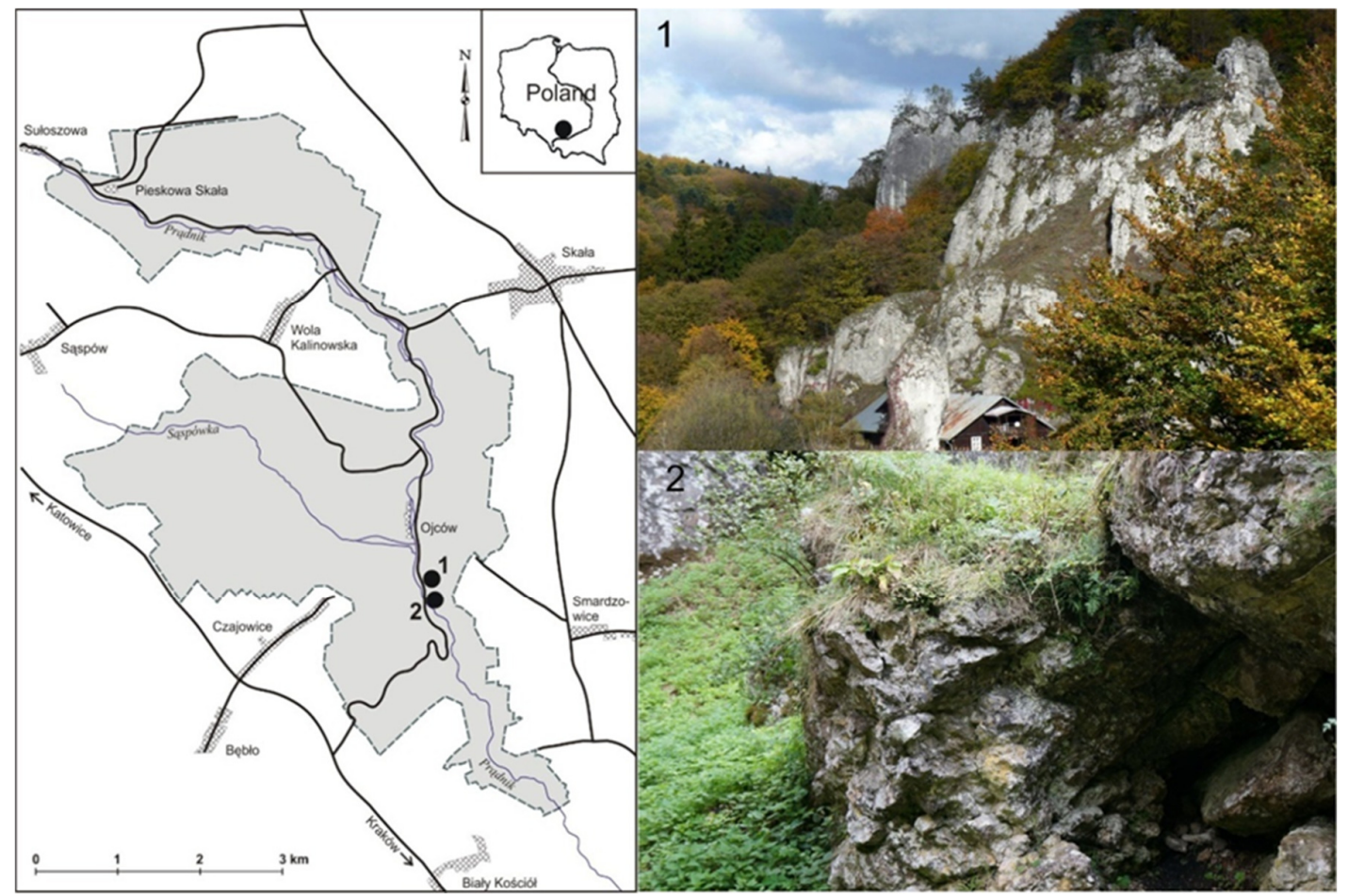

Figure 2. Location of research stands with Thymus praecox Opiz subsp. praecox in Ojców National Park (Southern Poland); 1 - Maidens' Rocks (Skały Panieńskie), 2 - Krukowski’s Rock (Skała Krukowskiego) (Photo A. Sołtys-Lelek)

Table 1. Environmental parameters: light intensity (L), temperature (T) and relative humid (RH) from SP - Maidens' Rocks, K - beneath Krukowski’s Rock in the Ojców National Park

\begin{tabular}{|c|c|c|c|c|c|c|}
\hline \multirow{2}{*}{ Parameters } & \multicolumn{2}{|c|}{$\mathrm{V}$} & \multicolumn{2}{c|}{ VI } & \multicolumn{2}{c|}{ VII } \\
\cline { 2 - 7 } & $\mathrm{SP}$ & $\mathrm{K}$ & $\mathrm{SP}$ & $\mathrm{K}$ & $\mathrm{SP}$ & $132.9 \mathrm{~b}$ \\
\hline $\begin{array}{c}\mathrm{L} \\
\left(\mu \mathrm{mol} \mathrm{m}{ }^{-2} \mathrm{~s}^{-1}\right)\end{array}$ & $284.0 \mathrm{a}$ & $147.5 \mathrm{~b}$ & $295.2 \mathrm{a}$ & $150.9 \mathrm{~b}$ & $256.0 \mathrm{a}$ & $16.5 \mathrm{~b}$ \\
\hline $\mathrm{T}\left({ }^{\circ} \mathrm{C}\right)$ & $20.3 \mathrm{a}$ & $19.5 \mathrm{~b}$ & $30.7 \mathrm{a}$ & $28.4 \mathrm{~b}$ & $18.9 \mathrm{a}$ & $62.59 \mathrm{a}$ \\
\hline $\mathrm{RH}(\%)$ & $42.73 \mathrm{~b}$ & $53.91 \mathrm{a}$ & $40.01 \mathrm{~b}$ & $63.89 \mathrm{a}$ & $50.23 \mathrm{~b}$ & \\
\hline
\end{tabular}

Note: months: V, VI, VII; a, b, c - values differ significantly according to Tukey test at $\mathrm{p} \leq 0.05$

Granulometry of soil samples in the $80 \mathrm{~nm}-2 \mathrm{~mm}$ measuring range (Fritsch laser particle size meter) were also analysed. The percentage of granular fractions was determined by the Bouyoucos-Casagrande areometric method in Prószyński's modification (PN-ISO 11277: 2005, 2005). The soils were classified according to USDA standards (Polskie Towarzystwo Gleboznawcze, 2009). The soil granulometric parameters of the above-mentioned stands are presented in Table 2.

On the studied stands occur initial rendzinas - soils developed on limestone bedrock, with the profile structure type A-AC-Cca. They are characterised by very thin humus level (A), which was created with the participation of herbaceous plant remains. The analysed stands do not differ significantly in terms of granulometric composition. In both cases sand, especially fine-grained, dominates. The dust fraction and clay have a scant share, and their genesis is associated with the roots of plants occurred in throughout the solum. The analysis was carried out at the humus level (A), and the presence of this fraction increases the soil's water capacity and provides better ecological conditions for xerothermic grasslands. 
Table 2. Basic granulometric parameters of soil in natural sites from which Thymus praecox Opiz subsp. praecox plant material was sampled in the Ojców National Park; SP - Maidens' Rocks, K - beneath Krukowski’s Rock

\begin{tabular}{|c|c|c|c|c|c|c|c|c|c|}
\hline \multirow[b]{2}{*}{ Profile } & \multicolumn{4}{|c|}{ Silt } & \multicolumn{4}{|c|}{ Sand } & \multirow{2}{*}{$\begin{array}{c}\text { PTG } 2008 \\
\text { with } \\
\text { standard } \\
\text { USDA }\end{array}$} \\
\hline & Clay & Fine & Coarse & $\begin{array}{l}\text { Very } \\
\text { fine }\end{array}$ & Fine & Medium & Coarse & $\begin{array}{l}\text { Very } \\
\text { coarse }\end{array}$ & \\
\hline \multirow{2}{*}{ SP } & 2 & 11 & 13 & 19 & 30 & 20 & 5 & 0 & ls \\
\hline & 2 & 15 & 18 & 20 & 23 & 19 & 4 & 0 & $\mathrm{sl}$ \\
\hline \multirow{2}{*}{$\mathrm{K}$} & 2 & 13 & 10 & 13 & 21 & 13 & 25 & 3 & ls \\
\hline & 3 & 15 & 22 & 22 & 21 & 14 & 4 & 0 & sl \\
\hline
\end{tabular}

Note: PTG - particle size distribution and textural classes of soils and mineral materials - classification of polish society of soil science 2008; ls - loamy sand, sl - sandy loam; analysis was performed using the Fritsch laser particle sizer; measurement range: $80 \mathrm{~nm}-2 \mathrm{~mm}$, mean $=5$

\section{Fresh and dry mass and tissue water content}

The plant material was weighed on a scale (Radwag WPS 210, Poland), and dried in a dryer (Wamed SUP-100, Poland) for 48 hours at $105^{\circ} \mathrm{C}$ to analyse the dry mass. Based on the obtained masses, the tissue water content was determined according to Black and Pritchard (2002).

\section{Chlorophyll content}

The chlorophyll content ( $\mathrm{Chl} a, b, a+b$ and $a / b)$ in $T$. praecox subsp. praecox leaves was determined according to Barnes et al. (1992). Fresh plant material was extracted in $3 \mathrm{ml}$ dimethyl sulfoxide (SIGMAAldrich) at $65^{\circ} \mathrm{C}$ for $12 \mathrm{~h}$. The absorbance of chlorophyll $a$ and $b$ was determined at wavelengths: $\lambda=665$ and $648 \mathrm{~nm}$, using the Aqarius 9500 spectrophotometer (Cecil Instruments, Cambridge, United Kingdom).

\section{Chlorophyll a fluorescence}

Chlorophyll a fluorescence of T. praecox subsp. praecox leaves was measured using a FMS1 fluorimeter (Hansatech, Norfolk, United Kingdom). In order to quenching the light phase of photosynthesis, the leaves were acclimatised to the dark for 30 minutes using clips, and then they were exposed to excitation light at 1000 $\mu \mathrm{mol} \times \mathrm{m}^{-2} \times \mathrm{s}^{-1}$, during $1 \mathrm{~s}$. Based on the measurements performed values of minimum fluorescence $\left(\mathrm{F}_{0}\right)($ Baker and Rosenquist, 2004), maximum fluorescence $\left(F_{m}\right)$, variable fluorescence $\left(F_{v}\right)$ and maximum photochemical PSII efficiency $\left(\mathrm{F}_{\mathrm{v}} / \mathrm{F}_{\mathrm{m}}=\left(\mathrm{F}_{\mathrm{m}}-\mathrm{F}_{0}\right) / \mathrm{F}_{\mathrm{m}}\right)$ (Björkmann and Demmig, 1987) were determined. In addition, a photochemical activity of photosystem II (PSII) was imaged using a FluorCam FC 800C (Photon Systems Instruments, Czech Republic). After earlier acclimatisation to darkness according to Lichtenthaler et al. (2004) method the following parameters were analysed: the stationary fluorescence $\left(\mathrm{F}_{\mathrm{t}}\right)$, the maximum photochemical efficiency of PSII ( $\left.\mathrm{QY}_{\max }\right)$, the non-photochemical quenching (NPQ) and the vitality of PSII (Rfd).

\section{Electrolyte leakage}

The degree of destabilisation of cell membranes of T. praecox subsp. praecox specimens was examined according to Barabasz-Krasny et al. (2018). Single thyme shoots were placed in polypropylene vials with $10 \mathrm{ml}$ distilled water and shaken for $3 \mathrm{~h}$ on a shaker (Labnet, Rocker, USA) to determine the outflow of electrolytes from live cells (E1). Then the plant material was frozen at $-70^{\circ} \mathrm{C}$. After $24 \mathrm{~h}$ the shaking procedure was repeated to the total electrolyte leakage from dead cells (E2) was measured. The percentage of electrolyte leakage (EL) was calculated according to the formula: $\mathrm{EL}=(\mathrm{E} 1 / \mathrm{E} 2) \times 100 \%$. 


\section{Statistical analysis}

The experiment was carried out in 2 independent series of 5 repetitions. The significance of differences between mean values $( \pm S D)$ were analysed by the ANOVA / MANOVA parametric test using the post hoc Tukey test $(\mathrm{HSD})(\mathrm{p} \leq 0.05)$ in Statistica 13.0 for Windows.

\section{Results}

\section{Fresh, dry mass and water content}

In the case of measurements of fresh and dry mass of $T$. praecox subsp. praecox shoots, the highest increase in masses was found in plants growing in the sunny stand, in relation to plants growing in the partially shaded stand. The tissue water content, in the first and second period of measurement dates (May and July), was higher in plants growing on the Krukowski's Rock $(\mathrm{K})$ stand. While, in the second measurement date (June), a higher water content was observed in T. praecox subsp. praecox from Maidens' Rocks (SP) stand (Table 3).

Table 3. Fresh, dry mass (g) and tissue water content (TWC) of Thymus praecox Opiz subsp. praecox collected from SP - Maidens' Rocks, K - beneath Krukowski’s Rock in the Ojców National Park

\begin{tabular}{|c|c|c|c|c|c|c|}
\hline \multirow{2}{*}{ Parameters } & \multicolumn{2}{|c|}{ V } & \multicolumn{2}{|c|}{ VI } & \multicolumn{2}{c|}{ VII } \\
\cline { 2 - 7 } & SP & K & SP & KP & K \\
\hline $\begin{array}{c}\text { Fresh mass } \\
(\mathrm{g})\end{array}$ & $0.141 \mathrm{a}$ & $0.122 \mathrm{a}$ & $0.125 \mathrm{a}$ & $0.043 \mathrm{~b}$ & $0.030 \mathrm{a}$ & $0.022 \mathrm{a}$ \\
\hline $\begin{array}{c}\text { Dry mass } \\
(\mathrm{g})\end{array}$ & $0.048 \mathrm{a}$ & $0.038 \mathrm{~b}$ & $0.035 \mathrm{a}$ & $0.014 \mathrm{~b}$ & $0.010 \mathrm{a}$ & $0.006 \mathrm{~b}$ \\
\hline $\begin{array}{c}\text { TWC } \\
(\mathrm{au})\end{array}$ & $0.0066 \mathrm{~b}$ & $0.0069 \mathrm{a}$ & $0.0072 \mathrm{a}$ & $0.0068 \mathrm{~b}$ & $0.0067 \mathrm{~b}$ & $0.0073 \mathrm{a}$ \\
\hline
\end{tabular}

Note: months: V, VI, VII; a, b, c - values differ significantly according to Tukey test at $\mathrm{p} \leq 0.05$

\section{Chlorophyll content}

In Thymus praecox subsp. praecox leaves significant differences in the chlorophyll $a$ and $b$ content between plants growing in the sunny (SP) and partially shaded (K) stands were found (Figure 3). The chlorophyll a content was lower in May, compared to the content of this pigment in June and July. Regardless of the measurement date, the chlorophyll a content was lower in thymus plants growing in the sunny stands, in relation to the plants from the partially shaded stands. The highest chlorophyll a content in T. praecox subsp. praecox plants from Krukowski's Rock stands during the optimal vegetation (June) was found. In June and July, the chlorophyll $b$ concentration was higher in plants growing on the Krukowski's Rock $(\mathrm{K})$ stand. At the Maidens' Rocks (SP) stand, the chlorophyll $b$ content was the highest in May. In the other two periods of the study, the chlorophyll $b$ content in leaves was significantly lowest.

The total chlorophyll $a$ and $b$ content was higher in plants growing on the Krukowski's Rock $(\mathrm{K})$ stand, regardless of the vegetation period. In the first measurement period (May), the lowest chlorophyll $a+b$ concentration, in plants growing on the Maidens' Rocks (S) stand, was observed. In June, the highest total chlorophyll content, in plants growing in the partially shaded stand, was found. The chlorophyll $a / b$ ratio

varied depending on the measurement period. Regardless of the light intensity at the studied stands, along with the growth and development of thyme plants, an increase in the value of this parameter was demonstrated. 

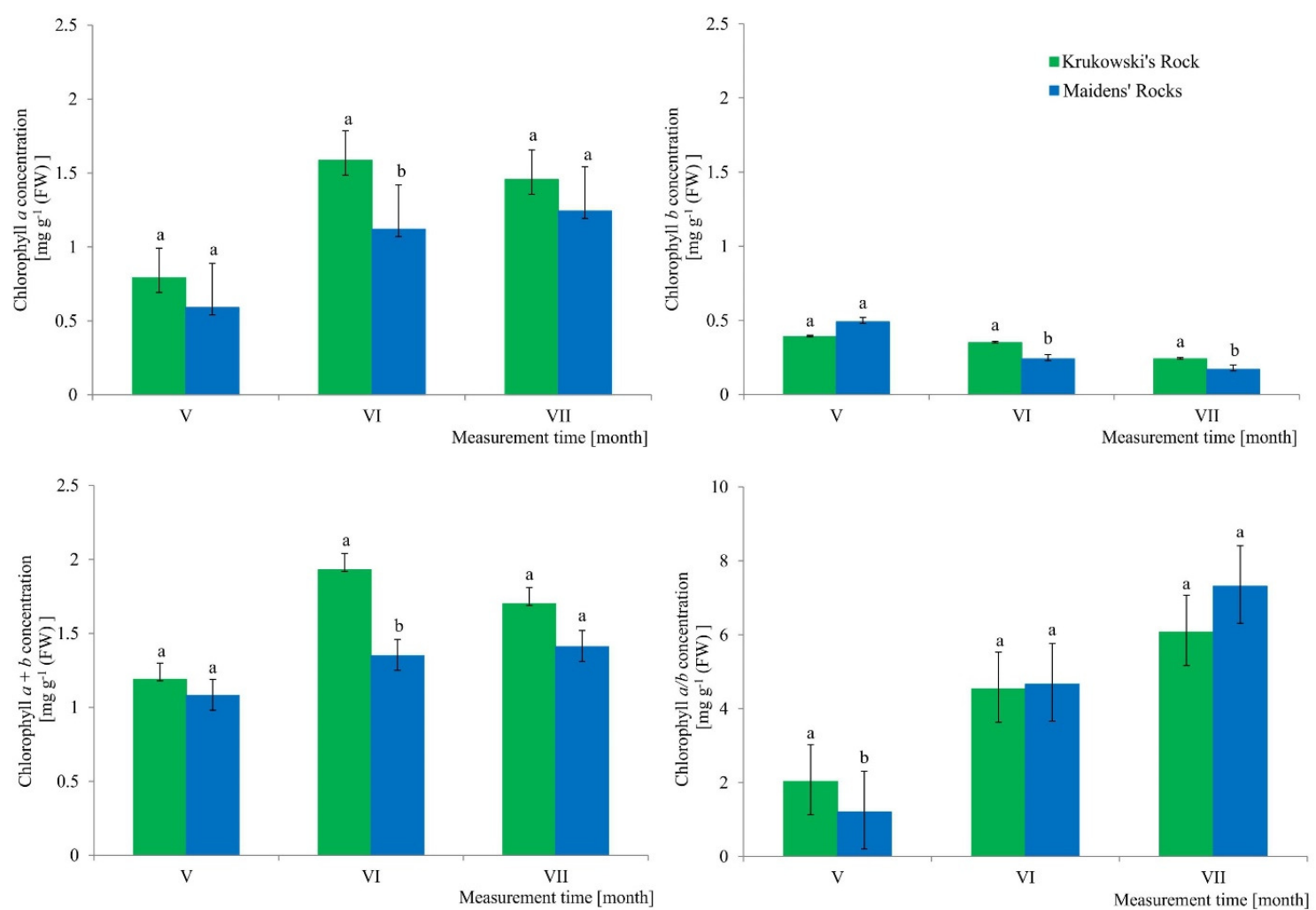

Figure 3. Chlorophyll content of Thymus praecox Opiz subsp. praecox collected from Maidens' Rocks, beneath Krukowski's Rock in the Ojców National Park in different time (months: V, VI, VII)

Note: $a, b, c$ - values differ significantly according to Tukey test at $\mathrm{p} \leq 0.05$

\section{Chlorophyll a fluorescence}

Based on the chlorophyll a fluorescence measurement, a various effect of light intensity on the photosynthetic activity of $T$. praecox subsp. praecox was observed (Table 4).

In May, the minimum fluorescence $\left(F_{0}\right)$, maximum fluorescence $\left(F_{m}\right)$ and variable fluorescence $\left(F_{v}\right)$ values were significantly higher in plants growing in the partially shaded stand, compared to the values of these parameters in plants from the sunny stand. In the other two measurement dates, the increase of the fluorescence parameters values was significantly higher in T. praecox subsp. praecox from the sunny stand, compared to the plants from the shady stand. Regardless of the vegetation period of plants, the maximum photochemical PSII efficiency $\left(\mathrm{F}_{\mathrm{v}} / \mathrm{F}_{\mathrm{m}}\right)$ values were significantly higher in plants growing in the sunny stand, compared to plants from the partially shaded stand.

Table 4. Intensities of chlorophyll a fluorescence parameters in leaves of Thymus praecox Opiz subsp. praecox collected from SP- Maidens' Rocks, K - beneath Krukowski's Rock in the Ojców National Park in different time (months: V, VI, VII)

\begin{tabular}{|c|c|c|c|c|c|c|}
\hline \multirow{2}{*}{ Parameters } & \multicolumn{2}{|c|}{$\mathrm{V}$} & \multicolumn{2}{c|}{ VI } & \multicolumn{2}{c|}{ VII } \\
\cline { 2 - 7 } & SP & K & SP & K & SP & $150.6 \mathrm{ab}$ \\
\hline $\mathrm{F}_{0}$ & $125.4 \mathrm{~b}$ & $141.8 \mathrm{~b}$ & $171.8 \mathrm{a}$ & $123.0 \mathrm{~b}$ & $183.2 \mathrm{a}$ & $1135.2 \mathrm{a}$ \\
\hline $\mathrm{F}_{\mathrm{m}}$ & $827.2 \mathrm{ab}$ & $1003.6 \mathrm{a}$ & $1241.0 \mathrm{a}$ & $521.8 \mathrm{~b}$ & $1262.4 \mathrm{a}$ & $1004.6 \mathrm{a}$ \\
\hline $\mathrm{F}_{\mathrm{v}}$ & $761.8 \mathrm{~b}$ & $801.8 \mathrm{~b}$ & $1069.2 \mathrm{a}$ & $482.8 \mathrm{c}$ & $1079.2 \mathrm{a}$ & $0.862 \mathrm{a}$ \\
\hline $\mathrm{F}_{\mathrm{v}} / \mathrm{F}_{\mathrm{m}}$ & $0.852 \mathrm{a}$ & $0.847 \mathrm{a}$ & $0.861 \mathrm{a}$ & $0.820 \mathrm{a}$ & $0.854 \mathrm{a}$ & 0 \\
\hline
\end{tabular}

Note: $\mathrm{a}, \mathrm{b}, \mathrm{c}$ - values differ significantly according to Tukey test at $\mathrm{p} \leq 0.05 ; \mathrm{F}_{0}$ - minimum fluorescence, $\mathrm{F}_{\mathrm{m}}$ - maximum fluorescence, $F_{v}$ - variable fluorescence, $F_{v} / F_{m}$ - maximum photochemical PSII efficiency 
At the first measurement period (May), the stationary fluorescence $\left(\mathrm{F}_{\mathrm{t}}\right)$ values were higher in plants from the Krukowski's Rock (K), compared to T. praecox subsp. praecox from the Maidens' Rocks (SP) (Figure 4). The highest $\mathrm{F}_{\mathrm{t}}$ values were observed in June, both on the one and second stands with T. praecox. In July, the plants from Maidens' Rocks $(\mathrm{SP})$ had slightly higher $\mathrm{F}_{\mathrm{t}}$ values than plants growing on Krukowski's Rock $(\mathrm{K})$ stand. $Q Y_{\max }$, in the first and the third measurement period (May and July), had lower values in relation to the plants from the second measurement period (June). In May, higher activity of plants growing on Maiden' Rocks

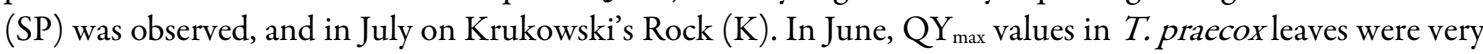
similar in both stands. NPQ and Rfd in the first measurement period (May) reached higher values in thymus plants growing on the Maidens' Rocks (SP). In the second measurement period (June), similar values of these parameters were revealed. The lowest NPQ and Rfd values were observed for plants from the Krukowski's Rock $(\mathrm{K})$ on the third measurement period (July).

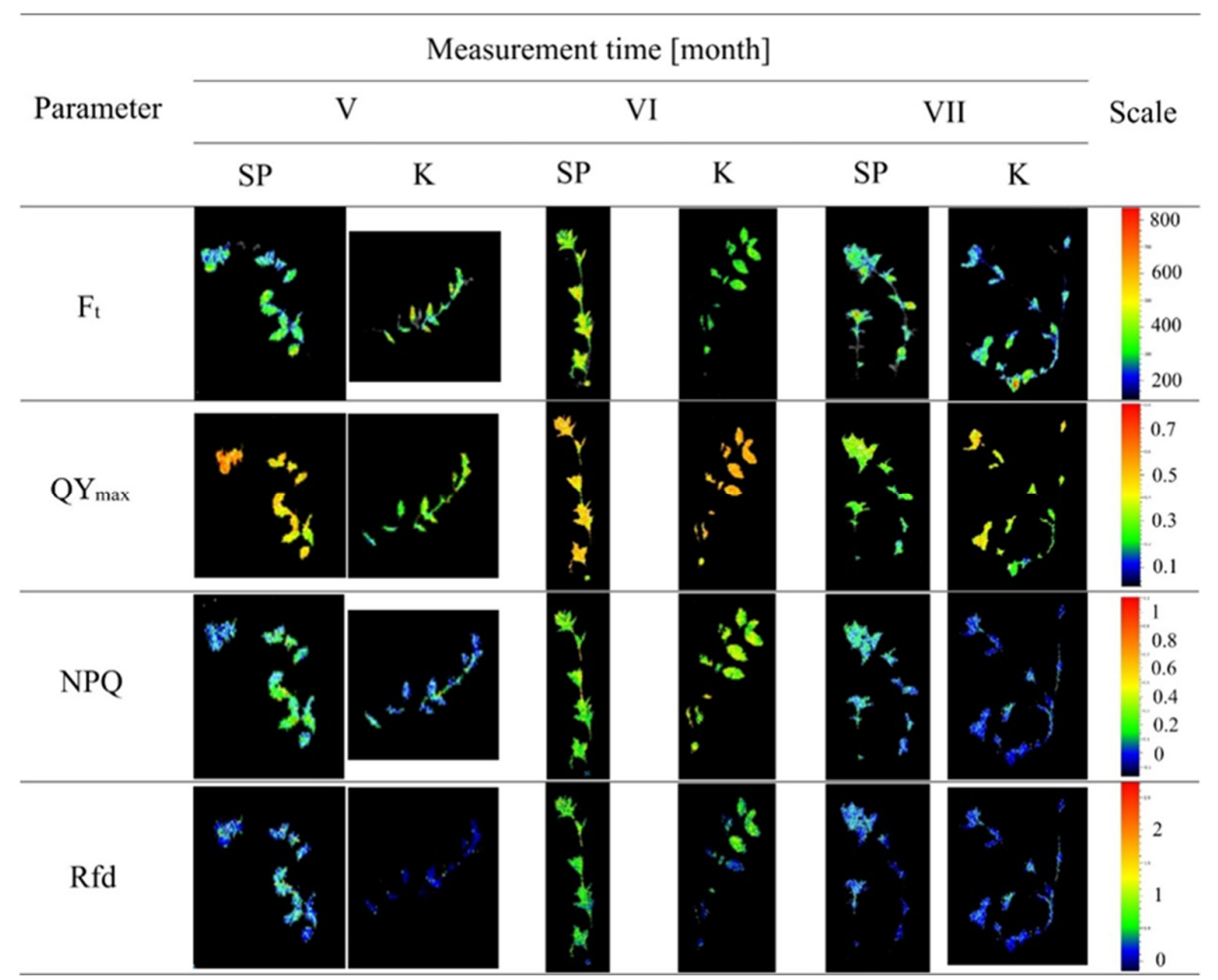

Figure 4. Imaging of chlorophyll a fluorescence parameters $\left(F_{t}\right.$ - the stationary fluorescence, $Q Y_{\max }$ - the maximum photochemical efficiency of PSII, NPQ - the non-photochemical quenching, Rfd - the vitality of PSII) in leaves of Thymus praecox Opiz subsp. praecox collected from SP - Maidens' Rocks, K - beneath Krukowski’s Rock in the Ojców National Park in different time (months: V, VI, VII)

\section{Electrolyte leakage}

Based on the measurements of electrolyte leakage through cell membranes from T. praecox subsp. praecox shoots, a significant increase in water and ion management destabilisation was observed in plants from the sunny stand only in May. In June and July, the electrolyte leakage was not only lower by half, compared to the May measurements, but definitely higher in plants growing in the partially shaded stand (Figure 5). 


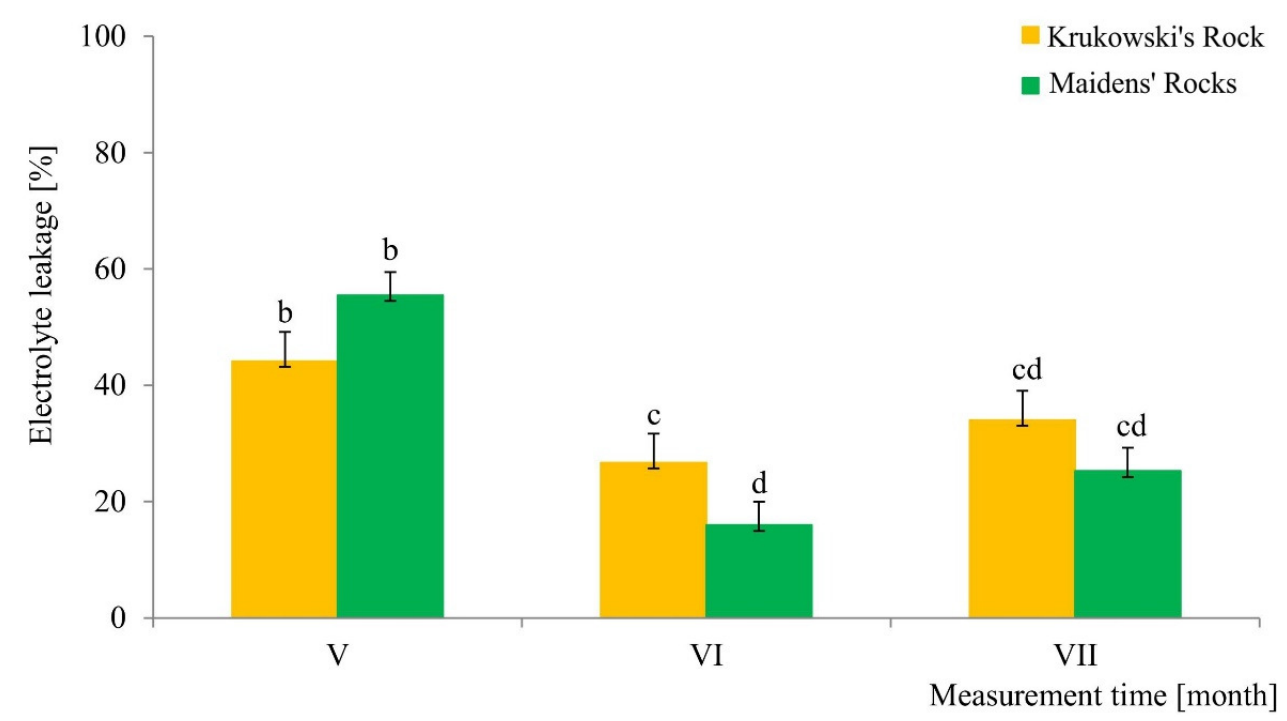

Figure 5. Electrolyte leakage of Thymus praecox Opiz subsp. praecox collected from Maidens' Rocks, beneath Krukowski's Rock in the Ojców National Park in different time (months: V, VI, VII) Note: $\mathrm{a}, \mathrm{b}, \mathrm{c}$ - values differ significantly according to Tukey test at $\mathrm{p} \leq 0.05$

\section{Discussion}

The spectral composition and intensity of light reaching the plants have a fundamental impact on their growth and development (Tyagi and Gaur, 2003; Valladares and Niinemets, 2008). They decide not only about the course and efficiency of photochemical processes, but also contain information about the surrounding environment and allow the best adaptation to natural conditions (Pilarski et al., 2012). The quantity and quality of sunlight reaching the plants in shady stands allows maximum use of low radiation intensities in the long-term range. At stands with direct access to light, it enables the use of blue and near red radiation. Thus, it leads to the development of a photosynthetic apparatus best adapted to specific environmental conditions (Lichtenthaler et al., 1981; Yamamoto et al., 2008). Light capture depends on the angle of illumination, leaf anatomy and other morphological and physiological traits (Gutschick, 1999; Pearcy and Way, 2012). Few studies indicate how leaf features and trees crown architecture effect on the point of light compensation for whole plants (Baltzer and Thomas, 2007).

In the Ojców National Park Thymus praecox subsp. praecox occurs, among others on the Maidens' Rocks (SP) located in the south-eastern part of the Park and under the Krukowski's Rock (K) in the northeastern part of the ONP, where differences in the light intensity, temperature and air humidity were demonstrated (Table 1). These differences are also confirmed by other parameters given from these stands, e.g. the annual total radiation (annual irradiation) - on the Maidens' Rocks (SP) stand it is 3.500-3.600 MJ m and under Krukowski's Rock $(\mathrm{K})$ stand it is estimated at 3.400-3.500 MJ.m $\mathrm{m}^{-2}$ (Wojkowski and Caputa, 2009). However, it is worth noting that these values are not diametrically different, which confirms the strict attachment of this species to xerothermic habitats. Soil preferences are an additional premise for its - in both stands T. praecox occurs on sandy rendzinas (Table 2), rich in calcium (Pawłowski, 1967). Therefore, in the analysed stands T. praecox subsp. praecox belongs to thermophilic species, typical for xerothermic grasslands, which is why the availability of the right quantity of light is a factor so important for its survival in the natural conditions.

The diversity of morphological and physiological features of T. praecox subsp. praecox plants growing in different lighting conditions provides information on their degree of acclimatisation in a diverse habitat. Plant morphology depends not only on endogenous growth processes, but primarily on environmental factors 
(Barthélémy and Caraglio, 2007). The analysis of $T$. praecox plant masses showed that significantly higher values of these parameters were for plants from the sunny stand (SP), regardless of the measurement period (Table 3). In the literature have already been observed similar relationships. For example, Zang et al. (2003) and Mielke and Schaffer (2010) found a decreased in biomass production of plants growing at low light intensity. Low radiation levels lead to an increase in leaf surface area and plant height. Meanwhile, the high radiation intensity is associated with an increase in leaf thickness, by increasing the number of cell layers, or by developing palisade layer and parenchyma tissue. These types of modifications help prevent damage caused by excessive quantity of light reaching the leaves (Matos et al., 2009).

Excess light reduces the content of photosynthetic pigments, which are responsible for its absorption (Wittmann et al., 2001; Pilarski et al., 2012). These reactions are the result of acclimatisation strategies developed by plants for specific conditions (Yang et al., 2007; Mielke and Schaffer, 2010; Możdżeń et al., 2014; Możdżeń, 2019). Acclimatisation involves a change in metabolic processes (including light collection and $\mathrm{CO}_{2}$ capture), ranging from adjusting leaf morphology to changes in the stoichiometry of the photosynthetic apparatus (Wright et al., 2004; Kono and Terashima, 2014, 2016; Zheng et al., 2014). One of the defence strategies of plants is a significant increase in the number of photosynthetic pigments that act as antennas, absorbing the required light energy (Chen, 2007). They show a higher efficiency of light absorption per unit of leaf biomass, enabling the plant to achieve better carbon balance, while limiting light (Enriquez and SandJensen, 2003; Li and Kubota, 2009). In T. praecox subsp. praecox studies, the chlorophyll a content decreased with increasing of light exposure. The chlorophyll $b$ content, which is responsible for transmitting light energy during photosynthesis and obtaining more energy for its effective use, was lower in thymus plants from the sunny stand (SP) (Figure 3). These types of changes contribute to a reduction in the rate of electron transport in the light phase of photosynthesis and an increase in the likelihood of photoinhibition (Maxwell and Johnson, 2000; Miyata et al., 2015).

The low light intensity causes to reduce the thickness of the palisade layer and the parenchyma leaves. As a result, it reduces the photosynthetic activity of plants by reducing energy transport from PSII to PSI (Yao et al., 2017; Yang et al., 2018a; Możdżeń, 2019). One of the main factors in the regulation of photosynthesis and plant response to environmental conditions is chlorophyll a fluorescence (Dai et al., 2009). It is used to measure the activity of photosystem II (PSII) and photo-inhibition by determining the potential quantum efficiency under light and shadow (Rascher et al., 2010). T. praecox subsp. praecox studies showed that plants growing in the sunny stand were characterised by higher PSII photosynthetic activity (Table 4). Despite the high efficiency of excitation energy transfer between pigments in PSII $\left(\mathrm{F}_{0}\right)$ antennas, changes in the number of reduced electron acceptors in PSII $\left(\mathrm{F}_{\mathrm{m}}\right)$ were observed. These types of changes contribute to the dissipation of excitation energy in the form of heat $\left(\mathrm{F}_{\mathrm{v}}\right)$, and lead to disturbances in the splitting of water, adversely affecting on the maximum photochemical efficiency of plants $\left(\mathrm{F}_{\mathrm{v}} / \mathrm{F}_{\mathrm{m}}\right)$ (Krause and Weis, 1991; Guidi et al., 2007). Other limiting factors may be the dissociation of LHCII proteins from the cortical part of PSII or degradation of the D1 protein and inactivation of reaction centres in PSII (Havaux, 1993; Rintamaki et al., 1995). One of the mechanisms to deal with adverse environmental conditions is to limit the use of excitation energy and transport speed.

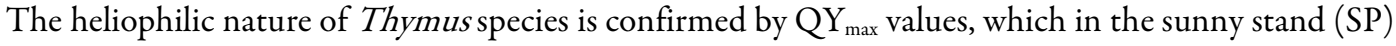
were clearly higher than in the shaded stand (K) (Figure 4). These types of plant responses are most likely related to leaf structure and high energy radiation absorption (Van Rensen and Vredenberg, 2011). Plants growing in shadow have a relatively low ability to transport electrons in photosynthesis and to bind $\mathrm{CO}_{2}$ (Lichtenthaler and Babani, 2004; Schumann et al., 2017). Changes in the $\mathrm{F}_{\mathrm{v}} / \mathrm{F}_{\mathrm{m}}$ and $\mathrm{QY}$ max values effect on the non-photochemical quenching (NPQ) activity. They are generally associated with the relative speed of electron transport and result from the dissipation of excitation energy in the heat form (Maxwell and Johnson, 2000; Proctor and Smirnoff, 2000). According to Proctor (2005) NPQ increases with increasing radiation intensity. However, plants to minimize PSII damage, depending on the species, development phase and stand of occurrence, still shape photo-protective mechanisms and multistage repair cycles (Kirchhoff, 2014). One 
example of regulating the quantity of light reaching the plants is rearrangement of the position of chloroplasts in the cell (Augustynowicz and Gabryś, 1999). In the case of the Rfd parameter in T. praecox subsp. praecox studies, in plants from the sunny stand an increase of its value was observed. This type of response indicates increased photosynthetic activity and no disorder of $\mathrm{CO}_{2}$ assimilation (Lichtenthaler and Rinderle, 1988; Schumann et al., 2017).

Water and ion management plays a significant role in plant response to environmental factors. It is connected, among others with the electrolytes leakage through cell membranes, which are dynamic structures and support numerous biochemical and biophysical reactions. Water-ion balance disorders mainly consist in changing metabolic processes, lowering enzymatic activity, reducing photosynthesis and changing fluidity of membranes, especially in the lipid layer (Campos et al., 2003; Demidchik et al., 2014). These types of changes are often associated with increased membrane permeability, effect on membranes integrity and cell division under stress. In extreme cases, they are irreversible and lead to cell death. The study shows that in T. praecox subsp. praecox growing in the sunny stand, the electrolytes leakage was significantly lower than in plants growing in the partially shaded stand (Figure 5). Once again, this is related to the fact that this species is a thermophilic taxon and the sunny stands are optimal for it for growth and development. Changes in the electrolyte leakage may be due to membrane damage. However, it should be remembered that the response of plants to stress depends not only on the species, variety, but also on the type and amount of stress factors acting on them (Prasch and Sonnewald, 2015; Możdżeń, 2019).

A thorough knowledge of issues related to the physiological adaptation of T. praecoxsubsp. praecox and the functioning of its photosynthetic apparatus positively progresses towards the possibility of growing this species in controlled conditions. This may be an additional safeguard for the existence of its endangered populations in the natural environment. However, at the current stage of knowledge about this species, the most important seems to be ensuring adequate light availability through active protection measures to stop overgrowth of rock complexes. The removal of trees and shrubs and their offshoots that could shadow $T$. praecox subsp. praecox populations may provide conditions preferred by this species at its existing stands. The intensity of light is undoubtedly one of the most important environmental factors, deciding not only about the intensity, but also about the possibility of the life processes of this species, and as studies have shown here, it is not a taxa showing high habitat flexibility - even partial shade is not a convenient habitat for it.

\section{Conclusions}

These studies confirm the fact that T. praecox subsp. praecox is an extremely heliophilic taxa and the sunny stands are optimal for it. It is closely related to this type of habitat, characterised by low environmental flexibility - relatively small changes in the availability of light negatively affect its growth and development.

(i) Productivity of fresh and dry mass of Thymus praecox subsp. praecox specimens from the sunny stand was higher regardless of the progress of the growing season, compared to plants from the partially shaded stand; however, the water content in tissues was generally lower in the sunny stand. (ii) The chlorophyll $a$ and $b$ content decreased with increasing light exposure and was significantly lower in the sunny stand, regardless of the progress of the growing season. (iii) in May, the minimum $\left(\mathrm{F}_{0}\right)$, maximum $\left(\mathrm{F}_{\mathrm{m}}\right)$ and variable $\left(\mathrm{F}_{\mathrm{v}}\right)$ fluorescence values were significantly higher in plants in the partially shaded stand; in June and July values of these parameters were higher in thymus plants growing in the sunny stand. (iv) The electrolyte leakage through cell membranes of $T$. praecox subsp. praecox shoots only in May was higher in plants growing in the sunny stand; in June and July, the outflow of electrolytes was not only lower by half, but definitely lower than for plants growing in the partially shaded stand. 


\section{Authors' Contributions}

Research concept and design: BB-K and AS-L. Acquisition and/or assembly of data: BB-K and KM. Data analysis and interpretation: BB-K and KM. Drafting the article: BB-K, KM and IT. Critical revision: BBK, KM and IT. Final approval: BB-K, KM, IT and AS-L. All authors read and approved the final manuscript.

\section{Acknowledgements}

This study was financially supported by the Pedagogical University of Krakow Grant (signature: WPBU / 2020/05/00172; registration number: BN.610-169 / PBU / 2020).

\section{Conflict of Interests}

The authors declare that there are no conflicts of interest related to this article.

\section{References}

Albert NW, Lewis DH, Zhang H, Irving LJ, Jameson PE, Davies KM (2009). Light-induced vegetative anthocyanin pigmentation in Petunia. Journal of Experimental Botany 60:2191-2202. https://doi.org/10.1093/jxb/erp097

Augustynowicz J, Gabryś H (1999). Chloroplast movements in fern leaves: correlation of movement dynamics and environmental flexibility of the species. Plant Cell and Environment 22:1239-1248. https://doi.org/10.1046/j.1365-3040.1999.00487.x

Avci AB (2011). Chemical variation on the essential oil of Thymus praecox ssp. scorpilii var. Laniger. International Journal of Agriculture and Biology 13:607-610.

Baker NR, Rosenquist E (2004). Applications of chlorophyll fluorescence can improve crop production strategies: an examination of future possibilities. Journal of Experimental Botany 55(403):1607-1621. https://doi.org/10.1093/jxb/erh196

Baltzer JL, Thomas SC (2007). Determinants of whole-plant light requirements in Bornean rain forest tree saplings. Journal of Ecology 95:1208-1221. https://doi.org/10.1111/j.1365-2745.2007.01286.x

Barabasz-Krasny B, Możdżeń K, Sołtys-Lelek A, Stachurska-Swakoń A (2018). Biological traits of Impatiens parviflora DC. under different habitat conditions. Notulae Botanicae Horti Agrobotanici Cluj-Napoca 46(1):277-285. https://doi.org/10.15835/nbha46110970

Barnes JD, Balaguer L, Manrique E, Elvira S, Davison AW (1992). A reappraisal of the use of DMSO for the extraction and determination of chlorophylls $a$ and $b$ in lichens and higher plants. Environmental and Experimental Botany 32:85-100. https://doi.org/10.1016/0098-8472(92)90034-Y

Barthélémy D, Caraglio Y (2007). Plant architecture: a dynamic, multilevel and comprehensive approach to plant form, structure and ontogeny. Annals of Botany 99:374-407. https://doi.org/10.1093/aob/mcl260

Bayat L, Arab M, Aliniaeifard S, Seif M, Lastochkina O, Li T (2018). Effects of growth under different light spectra on the subsequent high light tolerance in rose plants. AoB Plants 10(5):ply052. https://doi.org/10.1093/aobpla/ply052

Biderman AW (1991). Wstępne wyniki badań nad biologią populacji Thymus praecox Opiz jako przykład badań warunkujących skuteczną ochronę zagrożonych gatunków roślin naczyniowych (Preliminary results of the research on the population biology of Thymus praecox Opiz as an example of research conditioning effective protection of endangered vascular plant species). Prądnik, Prace i Materiały Muzeum Władysława Szafera 3:193208. (In Polish)

Biderman AW, Bąba W (2001). Thymus praecox Opiz, In: Kaźmierczakowa R, Zarzycki K (Eds). Polska Czerwona Księga Roślin (Polish Red Book of Plants). Władysław Szafer Institute of Botany, PAN, Kraków, pp 320-321. (In Polish) 
Björkman O, Demmig B (1987). Photon yield of $\mathrm{O}_{2}$ evolution and chlorophyll fluorescence characteristics at $77 \mathrm{~K}$ among vascular plants of diverse origins. Planta 170:489-504. https://doi.org/10.1007/BF00402983

Black M, Pritchard HW (2002). Desiccation and survival in plants: drying without dying. CAB International, Wallingford, UK.

Campos PS, Quartin V, Ramalho JC, Nunes MA (2003). Electrolyte leakage and lipid degradation account for cold sensitivity in leaves of Coffea sp. plants. Journal of Plant Physiology 160(3):283-292. https://doi.org/10.1078/0176-1617-00833

Carvalho RF, Takaki M, Azevedo RA (2011). Plant pigments: the many faces of light perception. Acta Physiologiae Plantarum 33:241-248. https://doi.org/10.1007/s11738-010-0533-7

Chen XH (2007). Exploring the adaptation mechanism of the shade plant to shading environment. Bulletin Biology 71:853-859. (In Chinese)

Dai YJ, Shen ZG, Ying L, Wang LL, Hannaway D, Lu H (2009). Effects of shade treatments on the photosynthetic capacity, chlorophyll fluorescence, and chlorophyll content of Tetrastigma hemsleyanum Diels et Gilg. Environmental and Experimental Botany 65:177-182. https://doi.org/10.1016/j.envexpbot.2008.12.008

Demidchik V, Straltsova D, Medvedev SS, Pozhvanov GA, Sokolik A, Yurin V (2014). Stress-induced electrolyte leakage: the role of $\mathrm{K}+$-permeable channels and involvement in programmed cell death and metabolic adjustment. Journal of Experimental Botany 65(5):1259-1270. https://doi.org/10.1093/jxb/eru004

Duchoň M (2012). Thymus praecox Opiz subsp. praecox. Retrieved 2020 February 12 from https://botany.cz/cs/thymus-praecox/

Enriquez S, Sand-Jensen K (2003). Variation in light absorption properties of Mentha aquatica L. as a function of leaf form: implications for plant growth. International Journal of Plant Sciences 164:125-136. https://doi.org/10.1086/344759

Euro+Med (2006-) Euro+Med PlantBase - the information resource for Euro-Mediterranean plant diversity. Retrieved 2020 February 10 from http://ww2.bgbm.org/EuroPlusMed/

Frank J, Sterck FJ, Duursma RW, Valladares F, Cieslak M, Weemstra M (2013). Plasticity influencing the light compensation point offsets the specialization for light niches across shrub species in a tropical forest understorey. Journal of Ecology 101:971-980. https://doi.org/10.1111/1365-2745.12076

Guidi L, Mori S, Degl'Innocenti E, Pecchia S (2007). Effects of ozone exposure or fungal pathogen on white lupin leaves as determined by imaging of chlorophyll a fluorescence. Plant Physiology and Biochemistry 45(10-11):851-857. https://doi.org/10.1016/j.plaphy.2007.07.001

Gutschick VP (1999). Biotic and abiotic consequences of differences in leaf structure. New Phytology 143:3-18. https://doi.org/10.1046/j.1469-8137.1999.00423.x

Harper JL (1981). The meaning of rarity. In: Synge H (Ed). The biological aspects of rare plant conservation. John Wiley \& Sons, New York, pp 189-203.

Havaux M (1993). Rapid photosynthetic adaptation to heat stress triggered in potato leaves by moderately elevated temperatures. Plant, Cell and Environment 16:461-467. https://doi.org/10.1111/j.1365-3040.1993.tb00893.x

Karbstein K, Tomasello S, Prinz K (2019). Desert-like badlands and surrounding (semi-) dry grasslands of central Germany promote small-scale phenotypic and genetic differentiation in Thymus praecox. Ecology and Evolution 9:14066-14084. https://doi.org/10.1002/ece3.5844

Kirchhoff H (2014). Structural changes of the thylakoid membrane network induced by high light stress in plant chloroplasts. Philosophical Transactions of the Royal Society B: Biological Sciences 369(1640):2013-2025. https://doi.org/10.1098/rstb.2013.0225

Kono M, Terashima I (2014). Long-term and short-term responses of the photosynthetic electron transport to fluctuating light. Journal of Photochemistry and Photobiology B: Biology 137:89-99. https://doi.org/10.1016/j.jphotobiol.2014.02.016

Kono M, Terashima I (2016). Elucidation of photoprotective mechanisms of PSI against fluctuating light photoinhibition. Plant and Cell Physiology 57:1405-1414. https://doi.org/10.1093/pcp/pcw103

Krause GH, Weis E (1991). Chlorophyll fluorescence and photosynthesis: The basics. Annual Review of Plant Physiology and Plant Molecular Biology 42:313-349. https://doi.org/10.1146/annurev.pp.42.060191.001525

Li Q, Kubota C (2009). Effects of supplemental light quality on growth and phytochemicals of baby leaf lettuce. Environmental and Experimental Botany 67:59-64. https://doi.org/10.1016/j.envexpbot.2009.06.011 
Lichtenthaler HK, Babani F (2004). Light adaptation and senescence of the photosynthetic apparatus. Changes in pigment composition, chlorophyll fluorescence parameters and photosynthetic activity. In: Papageorgiou GC, Govindjee (Eds). Chlorophyll a fluorescence: a signature of photosynthesis. Springer, pp 713-736.

Lichtenthaler HK, Buschmann C, Döll M, Fietz HJ, Bach T, Kozel U, ... Rahmsdorf U (1981). Photosynthetic activity, chloroplast ultrastructure, and leaf characteristics of high-light and low-light plants and of sun and shade leaves. Photosynthesis Research 2(2):115-141. https://doi.org/10.1007/BF00028752

Lichtenthaler HK, Buschmann C, Knapp M (2004). Measurement of chlorophyll fluorescence kinetics (Kautsky effect) and the chlorophyll fluorescence decrease ratio (RFd-values) with the PAM-Fluorometer. In: Filek N, BiesagaKościelniak J, Marcińska I (Eds). analytical methods in plant stress biology. The Franciszek Gorski Institute of Plant Physiology of the Polish Academy of Sciences, Krakau, p. 93-111.

Lichtenthaler HK, Rinderle U (1988). The role of chlorophyll fluorescence in the detection of stress conditions in plants. Critical Reviews in Analytical Chemistry 19:29-85. https://doi.org/10.1080/15476510.1988.10401466

Mártonfi P, Mártonfiová L (1996). Thymus chromosome numbers from Carpathians and Pannonia. Thaiszia - Journal of Botany 6:25-38.

Matos FS, Wolfgramm R, Cavatte PC, Villela FG, Ventrella MC, DaMatta FM (2009). Phenotypic plasticity in response to light in the coffee tree. Environmental and Experimental Botany 67:421-427. https://doi.org/10.1016/j.envexpbot.2009.06.018

Maxwell K, Johnson GN (2000). Chlorophyll fluorescence - a practical guide. Journal of Experimental Botany 51(345):659-668. https://doi.org/10.1093/jxb/51.345.659

Meusel H, Jäger E, Rauschert S, Weinert E (1978). Vergleichende Chorologie der zentraleuropäischen Flora. II. Karten (Comparative chorology of Central European flora. II. Cards). Gustav Fischer Verlag, Jena. (In German)

Mielke MS, Schaffer B (2010). Photosynthetic and growth responses of Eugenia uniflora L. seedlings to soil flooding and light intensity. Environmental and Experimental Botany 68:113-121. https://doi.org/10.1016/j.envexpbot.2009.11.007

Miyata K, Ikeda H, Nakaji M, Kanel DR, Terashima I (2015). Rate constants of PSII photoinhibition and its repair, and PSII fluorescence parameters in field plants in relation to their growth light environments. Plant and Cell Physiology 56(9):1841-1854. https://doi.org/10.1093/pcp/pcv107

Możdżeń K (2019). Wpływ składu spektralnego światła na wybrane procesy fizjologiczne mchów w warunkach stresu ozonowego (Impact of spectral composition of light on selected physiological processes of mosses under ozone stress conditions). Wydawnictwo Naukowe Uniwersytetu Pedagogicznego, Kraków, 128 pp. (In Polish) https://doi.org/10.24917/97883808462

Możdżeń K, Saja D, Ryś M, Skoczowski A (2014). Impact of light spectral composition on the length and weight of the gametophyte Polytrichiastrum formosum (Hedw.) G.L.Sm., Plagiomnium cuspidatum (Hedw.) T.J.Kop. and Pleurozium schreberi (Brid.) Mitt. Modern Phytomorphology 5:73-78.

Pawłowski B (1967). Rozmieszczenie geograficzne kilku macierzanek (Thymus L.) w Polsce i zachodniej Ukrainie (Geographical distribution of several thymes (Thymus L.) in Poland and western Ukraine). Fragmenta Floristica et Geobotanica 13(1):15-50. (In Polish)

Pearcy RW, Way DA (2012). Two decades of sunfleck research: looking back to move forward. Tree Physiology 32:10591061. https://doi.org/10.1093/treephys/tps084

Pilarski J, Tokarz K, Kocurek M (2012). Adaptacja roślin do składu spektralnego i intensywności promieniowania (Adaptation of plants to spectral composition and radiation intensity). Prace Instytutu Elektrotechniki 256:223-236. (In Polish)

PN-ISO 11277:2005 (2005). Jakość gleby - Oznaczanie składu granulometrycznego w mineralnym materiale glebowym Metoda sitowa i sedymentacyjna (Soil quality - Determination of the granulometric composition in mineral soil material - Sieve and sedimentation method).

Polskie Towarzystwo Gleboznawcze (2009). Klasyfikacja uziarnienia gleb i utworów mineralnych - PTG 2008 (Particle size distribution and textural classes of soils and mineral materials - classification of Polish Society of Soil Science 2008). Roczniki Gleboznawcze 60(2):5-16. (In Polish)

Prasch CM, Sonnewald U (2015). Signaling events in plants: stress factors in combination change the picture. Environmental and Experimental Botany 114:4-14. https://doi.org/10.1016/j.envexpbot.2014.06.020

Proctor MCF (2005). Why do Polytrichaceae have lamellae? Journal of Bryology 27:221-229. https://doi.org/10.1179/174328205X69968 
Proctor MCF, Smirnoff N (2000). Rapid recovery of photosystems on rewetting desiccation-tolerant mosses: chlorophyll fluorescence and inhibitor experiments. Journal of Experimental Botany 51:1695-1704. https://doi.org/10.1093/jexbot/51.351.1695

Rascher U, Liebig M, Lüttge U (2010). Evaluation of instant light-response curves of chlorophyll fluorescence parameters obtained with a portable chlorophyll fluorometer on site in the field. Plant and Cell Environment 23:13971405. https://doi.org/10.1046/j.1365-3040.2000.00650.x

Rintamaki E, Salo R, Lehtonen E, Aro EM (1995). Regulation of D1 protein-degradation during photoinhibition of photosystem-II in vivo phosphorylation of the D1 protein in various plant groups. Planta 195:379-386. https://doi.org/10.1007/BF00202595

RMS (2014). Rozporządzenie Ministra Środowiska z dnia 9 października 2014 r. w sprawie ochrony gatunkowej roślin Dz. U. 16 października 2014 r. Poz. 1409 (Regulation of the Minister of the Environment of October 9, 2014 on the protection of plant species, Journal of Laws October 16, 2014. Pos. 1409) (In Polish).

Rutkowski L (2004). Klucz do oznaczania roślin naczyniowych Polski (Key for determining vascular plants of Poland). PWN, Warszawa. (In Polish).

Schumann T, Paul S, Melzer M, Dörmann P, Jahns P (2017). Plant growth under natural light conditions provides highly flexible short-term acclimation properties toward high light stress. Frontiers in Plant Science 8:681. https://doi.org/10.3389/fpls.2017.00681

Smith H (1982). Light quality, photoreception, and plant strategy. Annual Review of Plant Physiology 33:481-518. https://doi.org/10.1146/annurev.pp.33.060182.002405

Steyn WJ, Wand SJE, Holcroft DM, Jacobs G (2002). Anthocyanins in vegetative tissues: a proposed unified function in photoprotection. New Phytologist 155:349-361. https://doi.org/10.1046/j.1469-8137.2002.00482.

Théry M (2001). Forest light and its influence on habitat selection. Plant Ecology 153:251-261. https://doi.org/10.1023/A:1017592631542

Trela-Sawicka Z (1972). Further cytological studies in the genus Thymus L. from Poland. Acta Biologica Cracoviensia, series Botanica 15:61-68.

Tyagi A, Gaur T (2003). Light regulation of nuclear photosynthetic genes in higher plants. Critical Reviews in Plant Sciences 22(5):417-452. https://doi.org/10.1080/07352680390243503

Valladares F, Niinemets U (2008). Shade tolerance, a key plant feature of complex nature and consequences. Annual Review of Ecology, Evolution, and 39:237-257. https://doi.org/10.1146/annurev.ecolsys.39.110707.173506

Van Rensen JJS, Vredenberg WJ (2011). Adaptation of photosystem II to high and low light in wild-type and triazineresistant Canola plants: analysis by a fluorescence induction algorithm. Photosynthesis Research 108:191-200. https://doi.org/10.1007/s11120-011-9680-y

Wittmann C, Aschan G, Pfanz H (2001). Leaf and twig photosynthesis of young beech (Fagus sylvatica) and aspen (Populus tremula) trees grown under different light regime. Basic and Applied Ecology 2:145-154. https://doi.org/10.1078/1439-1791-00047

Wojkowski J, Caputa Z (2009). Przestrzenne i czasowe zróżnicowanie promieniowania pochłoniętego na obszarze Ojcowskiego Parku Narodowego (Spatial and temporal differentiation of absorbed radiation in the Ojców National Park). Prądnik, Prace i Materiały Muzeum Władysława Szafera 19:169-180. (In Polish)

Wright IJ, Reich PB, Westoby M, Ackerly DD, Baruch Z, Bongers F, .. Villar R (2004). The worldwide leaf economics spectrum. Nature 428:821-827. https://doi.org/10.1038/nature02403

Yamamoto Y, Aminaka R, Yoshioka M, Khatoon M, Komayama K, Takenaka D, ... Yamamoto Y (2008). Quality control of photosystem II: impact of light and heat stresses. Photosynthesis Research 98:589-608. https://doi.org/10.1007/s11120-008-9372-4

Yang F, Fan Y, Wu X, Cheng Y, Liu Q, Feng L, ... Yang W (2018a). Auxin-to-gibberellin ratio as a signal for light intensity and quality in regulating soybean growth and matter partitioning. Frontiers in Plant Science 9:56. https://doi.org/10.3389/fpls.2018.00056

Yang F, Feng L, Liu Q, Wu X, Fan Y, Ali Raza M, .. Yang W (2018b). Effect of interactions between light intensity and red-to- far-red ratio on the photosynthesis of soybean leaves under shade condition. Environmental and Experimental Botany 150:79-87. https://doi.org/10.1016/j.envexpbot.2018.03.008

Yang XY, Ye XF, Liu GS, Wei HQ, Wang Y (2007). Effects of light intensity on morphological and physiological characteristics of tobacco seedlings. Chinese Journal of Apply Ecology 18:2642-2645. 
Yao X, Li C, Li S, Zhu Q, Zhang H, Wang H, .. Xie F (2017). Effect of shade on leaf photosynthetic capacity, lightintercepting, electron transfer and energy distribution of soybeans. Plant Growth Regulation 83:1-8. https://doi.org/10.1007/s10725-017-0307-y

Zarzycki K, Szeląg Z (2006). Red list of vascular plants in Poland. In: Mirek Z, Zarzycki K, Wojewoda W, Szeląg Z (Eds). Red list of plants and fungi in Poland. Władysław Szafer Institute of Botany, PAN, Kraków, pp 99.

Zheng B, Chen HG, Yan ZQ, Luo XZ, Duan LJ, He HG (2014). Effects of shade on morphological, anatomical and physiological properties of Patrinia villosa (Thunb.) Juss. leaves. Hubei Agricultural Sciences 53:3111-3115.
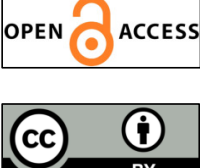

The journal offers free, immediate, and unrestricted access to peer-reviewed research and scholarly work. Users are allowed to read, download, copy, distribute, print, search, or link to the full texts of the articles, or use them for any other lawful purpose, without asking prior permission from the publisher or the author.

License - Articles published in Notulae Botanicae Horti Agrobotanici Cluj-Napoca are Open-Access, distributed under the terms and conditions of the Creative Commons Attribution (CC BY 4.0) License. (C) Articles by the authors; UASVM, Cluj-Napoca, Romania. The journal allows the author(s) to hold the copyright/to retain publishing rights without restriction. 